\title{
Surrealist Crucifixion by Dali
}

\author{
Ticiana Dine \\ Social Sciences in Albania, Faculty of Communication Sciences, European University of Tirana, Albania \\ Email: ticianadine@gmail.com
}

\section{Doi:10.5901/ajis.2016.v5n3s1p94}

\section{Abstract}

All this study refers to this Spanish surrealist artist of the twentieth century, who made a significant contribution to the surrealist movement not just as an artist but also as a researcher and analyst, who touched the psychological aspect of the human mind. He combined the philosophical, psychological, mystical, oneric of Freud, symbolism and surrealism elements presenting so a picture which is chaotic at first glance that confuses the observer and makes him understand it as a surreal one without going beyond perception not only symbolic but also the mystic one. One of the most powerful relationships and even mystical would be Dali and his wife Gala- with her influence on the artist's artworks. Surrealism was in fact a multi-dimensional movement, which affected various areas opening so different paths of research for many artists. Surrealism is known as a movement which was sustain not only in absolute freedom of the artist but also in manifestos written by Andre Breton, without forgetting the very social impacts of that time. One of the most popular figures of surrealism is Salvador Dali, who made a great contribution to overcoming the many surreal characteristic features. One of the characteristic of Dali's works is his treatment on Christ's crucifixion. From all other contemporaries Dali presents the crucifixion by a very different form which appears from time to time and as a chess game with cubes. Meanwhile Gala is presented dressed under the mantle of the Saint with a kind of estrangement in the treatment of His suffering and crucifixion. In this detailed analysis we understand his surrealism (of Dali) and perhaps his position as a believer.

Keywords: surrealism, Crucifixion, symbolism, sacred, mystical influence.

\section{Introduction}

Crucifixion was one of the most particularized motives which are treated primarily under an excessive religious spirit in order to provide biblical message. Many artists have stayed loyal to religious message handling it in iconography and wall paintings with a special precision. For a lot of years in art history we see many artists who touched the theme of crucifixion in a more personal way putting into it not just colors but also symbols that represent a concernment more personal or artistic toward these religious topics. In this study are analyzed some works that represent the Crucifixion in various forms to those in which the religious motive will be combined with a mystic personal concernment wherein the work will be decoded and couldn't be perceived by all the people as church asked for.

\section{From Realism to Symbolism}

The aspect of the crucifixion is one of the most touched motives by many artists as those of classical and modern art and until today. Crucifixion was a derogatory and insulting act leaving the crucified person to have a slow and suffering death where even the bodies of crucified persons were shredded and bleeding by beatings for their humiliation. Mostly the crucifixion is treated as a violent and bloody act and more damning one in terms of how the body of Christ suffers physical deformities adapting stringed up extension of body weight down. Sometimes the body of Christ appears weak, schematic, not natural, hairline and smaller than the other characters around (in the works of Hieronymus Bosch).

Meanwhile the figure of Christ at the crucifixion made by Grunewald appears overly dramatic, there is not a prospect, figures represent a decline and not communicating with each other, they incur schematization, while the crossed figure is the only one which occupies the leading place. Christ's body undergoes a deformation at knees colliding with each other while the feet and the palms of the hands which seem to suffer a contraction of muscles when his body languishes. 
Fig.1 Christ on the Cross-H. Bosch ${ }^{1}$
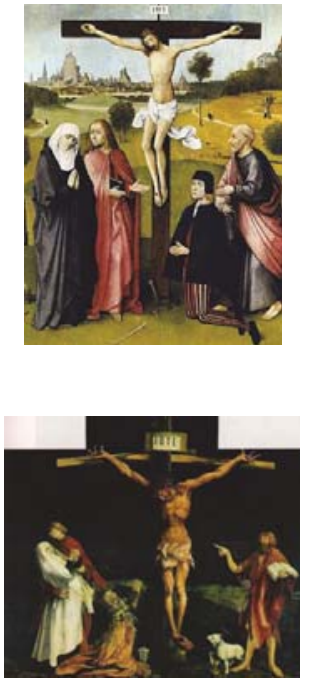

Fig.2 Mathias Grunewald

Differently it will be treated in the works of Francisco De Goya which would require more the humane and two dimensionality line. In artwork of Caravaggio (Fig. 3) the crucifixion is shown on the side from the top down, where for the first time we see a composition so brave in front of his crucifixion.

There do not see blood, nail junction of the suffering but, fear, feeling strong before his crucifixion act.

In Figure. 1 we see the separation of the two plans, one of crucifixion and the buildings in the background. In the picture is presented the life, knowledge, and death. On the left, in the back of St. Mary we see a crow and some bones which go further up at the feet of the saints where one of them is embedded with the cross of Christ. Also we found a skull, while in the hands of St. John is a book that shows knowledge of renaissance. St. John seems that by gestures shows about the afterlife, which never will belong to death: "If I will that he tarries till I come, what is that to thee?" (John 21:22)2

Figures do not represent suffering and are just as in Fig.2 where St. Maria seems surrendered by the pain of Christ loss. In both works is presented book-knowledge, the four characters, otherwise the following acts that appear three.

In the work of Caravaggio there appear three characters which are not divine, but individuals who are assigned to the crucifixion of St. Peter. The same thing we see also into the work of Dali below where the characters are not divine but people who represent the continuation of a monotonous life and do not belong to the divine or to the death and punishment.

If we stop over at (fig. 4) may see a very different attitude from the one that was first presented before surrealism. Dali presents Christ from an unusual perspective, viewing from above.

Fig.3 crucifixion of St. Peter by Caravaggio

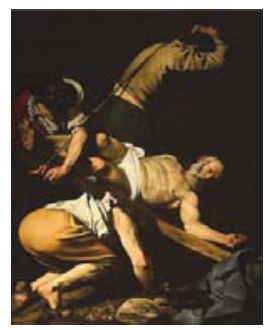

${ }^{1}$ Bosch. H. (2008). Falk. K. Goldenstone Press Benson, North Carolina (page.37)

${ }^{2}$ Bosch. H. (2008). Falk. K. Goldenstone Press Benson, North Carolina(page.37) 


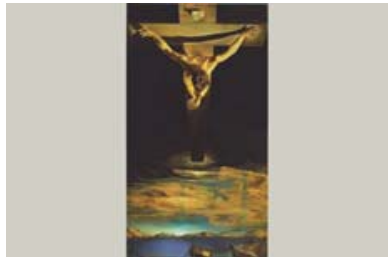

Fig.4 Christ of St. John of the Cross, 1951- S. Dali-1951³

The view looks not human but very much divine where Father himself sees his son from above. In the works presented so till Dali realizes this work, we see that Crucifixion was seen by a human perspective, where the presence of Mary and other saints tell of suffering and the Bible discourse.

In work of Dali we see no deity nor mourning, but death and rebirth at the same time. Even we see over there even part of the landscape of his hometown, which is treated in many of his works.

In 1950 Dali wrote that he had dreamed a dream space, precisely this image (Crucifixion) with colors and he considered this dream as the unity of the universe, Christ. Dali stated that he drew a triangle and a circle where he put the Christ inside of it. Making a parallel of lines between the open hands (fig.1- fig.2- Figure 3) and the conjoined legs is created a triangle and the head of Christ sitting down creates a circle inside the triangle itself. Thus he is creating Christian symbolism, the triangle of the Trinity and the circle as a symbol of the universe.
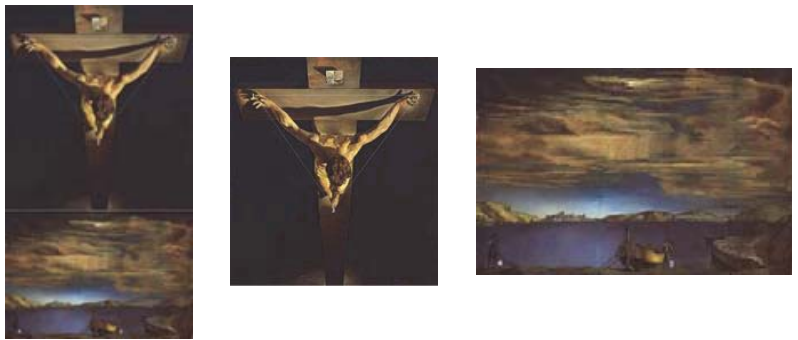

Figure of Christ in this work appear not die-away, describing a perfect vertical line, the body itself appears that requires not falling down even though his weight tends it.

Crucifixion of Dali is divided into two frames where the parallel below makes us to look the work on two plans that do not have a visual continuity rather than a philosophical continuity that make a whole picture. In the second plan where is depicting the fisherman to the left (fig. 4) and the other fisherman on the right (Fig. 5) there are part of a vital continuum and tranquility posing here the early landscape of his hometown.

We can say that the Crucifixion made by Dali is a different composition unlike many other Crucifixions made by artists before him. Compared with Grunewald, Caravaggio, Bosch or other artists who presented Crucifixion, Dali separated fully from them in content more dramatic but in philosophical way posing a Christ where no one mourns over him and even he himself does not seem to dying than a lifting process toward universe separating the religious and continuity of human life on the other side.

\section{From Religious to Mystic}

Dali also presents other cuboids Crucifixion, four dimensional, which makes a parallel with another Crucifixion (that is analyzed above). This Crucifixion represents again not suffering and bleeding, he seems disconnected from the cuboid cross creating thus a magnetic stand even though in front of naked body of Christ there appear four cubes that seem to play the role of the nailing.

The figure of Christ seems to sleep and it is almost as cross at his size, glorifying so more the figure of Christ. And 
the cross does not seem to represent the place of sacrifice and suffering by slow death but rather a cuboide in geometric shape which looks like a puzzle. Lighting in this work is to own Christ over his face and creating shade in his Crucifixion (shadow of hands on cubes) as well as to female figures which seems to represent the St. Mary herself.

This figure wearing a mantle seems that worships the image of Christ more than the weeping for him as just as it appears in other works by the artists or as is illustrated on his religious writings. This figure is also his own wife who played a key influencing role in creativity of Dali, Gala who appear in almost all his works as a mother, as a whore, as a wife filed in the tarot cards (cards of fortune) which Dali paints and finally, in this work she represents the biological mother of Christ.

Before we stay at the different Crucifixion of Dali let us focus on mystical interest of what had influenced on Dali for such a composition.

\begin{abstract}
"There are already some time that I am continuing to love my wife, whom I married seven years ago. Actually I begin to love her conform the law of the Roman Catholic Church (...)"4

"When Gala is resting, I can say that she resembles chapel of Tempieto di Bramanti, located near St. Peter Montozio in Rome. And as Stendhal in the Vatican and I later and in spite of him, I can put on a same plane her pride, her beautiful columns, and her soft and stable railings with her childish look and divine stairs with her smile." 5

Gala and her influence as an educated female is presented in this work as a saint, icy under St. John's knowledge about the return of Christ, which we saw at work of H.Bosch above (Figure 1).
\end{abstract}

Regarding the circle and triangle we can do also a parallelism with "Vitruvius Man" by Leonardo da Vinci, where the human figures it is depicted in a triangle, the latter within a circle. Thus it can be seen even the Crucifixion made by Dali as chronological circle within the triangle and circle or cuboid cross who again wants to create a certain shape within which can be introduced or supported in this case the figure of Christ.

Consequently the work takes not only religious or dimensional connotations just as is covered in many articles as four dimensional but it manages to establish a mathematical and religious connection to create not anymore a sense of death and suffering but a new form of rebirth or raising the Christ from the terrestrial to divine. Although into the work (Figure 1) of H.Bosch is given in narrative form the death with skull and bones the earth and the image of Christ hanging on the cross yet he does not yet belong to physical death and burial. Also in figure 2 of Grunewald we see more mourning but again seem the body of Christ still is not surrendering to death than to a physical and terrible suffering and exhaustion, which also testify also physical disproportion of Christ (hands are longer than the body).

If we return to Gala and her presence at the Crucifixion of Christ can say that the work "'Gala Contemplating the Mediterranean Sea which at Twenty Meters Becomes the Portrait of Abraham Lincoln- Homage to Rothko (second version), $1976^{6}$ presented her figures in Crucifixion as a space of overwhelming spatial frequency of a particular non human. Gala seems placed precisely between those parallels which in the work presented as the core of the cross, without undergoing a proper Crucifixion.

In this work we also see the same image of Christ's crucifixion as in picture 4 above where we have the division of space wherein the crucified Christ is seen again from the top, are the fiery colors and looks like a particle offline precisely from the above work (fig. 4).

Change in this work is that Gala 'undresses', she appears naked returned on her back, it seems that she hasn't a visual relationship with crucifixion nor mourners for him, or to worship him just as in the above work, but she appears as a woman who is an interior space where we wanted to enter into this space, Gala seems to see through a window the outer space. Again this ambiguous situation and non-religious relationship is crossed by cubes which inside of them put the Christ and outside this framework put the lower half of the body of Gala (from the waist down) with her feet. Although this view of a contemplative women through a window is a motif that Dali borrowed from his work when he paints his sister Figure at a Window, $1925^{7}$ (Fig. 6) but this view does not the same strain, because we can find a sense of Eros.

There are present the male and female, and in no work of that time St. Mary did appear naked and if in this artwork Gala did not embody Mary why she is placed in the same relationship with Christ seen from topside as in the work analyzed above (fig. 4).

${ }^{4}$ Dali, S. (2010). Jeta e fshehtë e Salvador Dalisë e treguar nga ai vetë (Secret life of Dali.) Tiranë: Onufri

${ }^{5}$ Dali, S. (2010). Jeta e fshehtë e Salvador Dalisë e treguar nga ai vetë.( Secret life of Dali.) Tiranë: Onufri

${ }^{6}$ Dali, S. (2004). Descharnes, R., dhe Nerret, G: Koln. Taschen GmbH (page. 653, images. 1447)

7Dali, S. (2004). Descharnes, R., dhe Nerret, G: Koln. Taschen GmbH (page. 91, images. 200) 
Here Dali played with interior and exterior, with the divine and its sustainability, with humane instincts that bring continuity of erotic life by the birth of a creature again. Dali also played in this work with the observation from above to below and from below to topside.

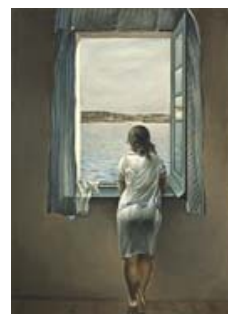

(Fig.6) Figure at a Window, 1925

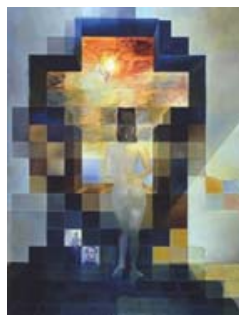

(Fig.7) Gala Contemplating the Mediterranean Sea which at Twenty

Meters Becomes the Portrait of Abraham Lincoln- Homage to Rothko (second version), 1976

This connection that Dali makes by the placement of the image of his wife is actually challenging to church principles, which are not dealt with this work being seen in a more artistic aspect. But if we submit a detailed analysis, this is more crucifixion according to Gala (in Gala way) making a parallelism with the Divine image itself.

Consequently, we see that the crucifixions in the works of Dali go beyond the religious aspect being raise in a range of more mystical (as Gala himself who was mystical and read the letters of fortune that then were condemned by the church), she was of authority and had a knowledge deeply connected with surrealism because she belonged to a solid family and was ex wife of Paul Eluard (where she participated in meetings of the surrealist artists since their beginnings, the place where she met Dali).

Consequently, we can say that Dali played with motifs which were somewhat affected by him and with religious hint but he defied them by embodying Gala with own figure of Mary as well as ambiguity of Gala with divinity and her nakedness in another work, which will not comply anymore with what quoted by church and Bible texts.

It was not an artistic and surreal maneuver of him but a symbolic and secret stand of him with his wife who was a figure who wore all the qualities to Dali. She was not placed to be offended or rejected biblical writings, but to present the Divine Mercy embodied to figure of Gala whom in Dali writings, in his works and in the book on the secret lives of his calls Gala as a leader and teacher of his, furthermore as his mother and his muse. In the same way was Maria for her son (and mostly as any mother for her son).

\section{Conclusion}

Crucifixion in the works of Dali appears in an aspect not only surreal but too mystical, where reading does not correspond just to the Bible and descriptive ones but with a symbolic and very mystic reading which challenged the compositions until then on plane Crucifixions (wall paintings) and two dimensional ones. The religious symbolism of Dali was mystical symbolism and separation of terrestrial dimension from the divine one in an upper and deeper philosophical level. 


\section{References}

Bosch. H. (2008). Falk. K. Goldenstone Press Benson, North Carolina Dali, S. (2004). Descharnes, R., dhe Nerret, G: Koln. Taschen GmbH Dali, S. (2005). Descharnes, R., dhe Nerret, G: Koln. Taschen GmbH Dali, S. (2006). Descharnes, R., dhe Nerret, G: Koln. Taschen GmbH Surealism (2005). TASCHEN GmbH. CathrinKlingsohr-LeroryUta Grosenick (Ed.) Fiebig, J. (2004). Dali Tarot. Spain. VEGAP

An Alternative Paradigm to the Oppression of Nuclear War: Salvador Dali's Painting of Christ of St. John of the Cross 